\title{
KRAS-mutation status in relation to colorectal cancer survival: the joint impact of correlated tumour markers
}

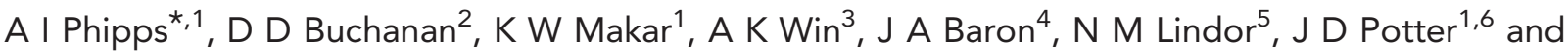 \\ P A Newcomb ${ }^{1}$
}

${ }^{1}$ Public Health Sciences Division, Fred Hutchinson Cancer Research Center, 1100 Fairview Avenue N., Seattle, WA 98109, USA; ${ }^{2}$ Cancer and Population Studies Group, Queensland Institute for Medical Research, 300 Herston Road, Herston, Queensland 4006, Australia; ${ }^{3}$ Centre for Molecular, Environmental, Genetic and Analytic Epidemiology, The University of Melbourne, 207 Bouverie Street, Parkville, Victoria 3010, Australia; ${ }^{4}$ Department of Medicine, University of North Carolina, 130 Mason Farm Road, Chapel Hill, NC 27599, USA; ${ }^{5}$ Department of Laboratory Medicine and Pathology, Mayo Clinic, 13400 E. Shea Boulevard, Scottsdale, AZ 85259, USA and ${ }^{6}$ Centre for Public Health Research, Massey University, Wellington, New Zealand

Background: Mutations in the Kirsten Ras (KRAS) oncogene are common in colorectal cancer (CRC). The role of KRAS-mutation status as a prognostic factor, however, is unclear. We evaluated the relationship between KRAS-mutation status and CRC survival, considering heterogeneity in this association by tumour and patient characteristics.

Methods: The population-based study included individuals diagnosed with CRC between 1998-2007 in Western Washington State. Tumour specimens were tested for KRAS exon 2 mutations, the BRAF p.V600E mutation, and microsatellite instability (MSI). We used Cox regression to estimate hazard ratios (HR) and $95 \%$ confidence intervals (Cl) for the association between KRAS-mutation status and disease-specific and overall survival. Stratified analyses were conducted by age, sex, tumour site, stage, and MSI. We conducted additional analyses combining KRAS-mutation, BRAF-mutation, and MSI status.

Results: Among 1989 cases, 31\% had KRAS-mutated CRC. Kirsten Ras (KRAS)-mutated CRC was associated with poorer diseasespecific survival ( $H R=1.37,95 \% \mathrm{Cl}: 1.13-1.66)$. This association was not evident in cases who presented with distant-stage CRC. Cases with KRAS-wild-type/BRAF-wild-type/MSI-high CRC had the most favourable prognosis; those with CRC exhibiting a KRAS- or BRAF-mutation and no MSI had the poorest prognosis. Patterns were similar for overall survival.

Conclusion: Kirsten Ras (KRAS)-mutated CRC was associated with statistically significantly poorer survival after diagnosis than KRAS-wild-type CRC.

The Kirsten Ras (KRAS) proto-oncogene encodes for a guanosine triphosphate (GTP)/guanosine diphosphate binding protein downstream of the epidermal growth factor receptor (EGFR) in the RAS/ RAF/MAPK pathway. Mutations in KRAS are evident in 30-40\% of colorectal tumours (Andreyev et al, 1998; Samowitz et al, 2000; Gnanasampanthan et al, 2001; Wang et al, 2003; Lee et al, 2008; De Roock et al, 2010a, 2010b; Nash et al, 2010; Roth et al, 2010; Hutchins et al, 2011; Imamura et al, 2012; Inoue et al, 2012). Based on evidence that the benefits of adjuvant treatment with anti-EGFR chemotherapy for distant-stage metastatic colorectal cancer (CRC) are limited to patients with KRAS-wild-type disease (Lin et al, 2011; Bokemeyer et al, 2012), testing for KRAS mutations is increasingly common in clinical practice in order to better direct treatment of CRC (Allegra et al, 2009). Although the role of KRASmutation status as a predictive biomarker for response to antiEGFR-targeted therapy is well supported, the role of KRAS as a

*Correspondence: Dr Al Phipps; E-mail: aphipps@fhcrc.org

Received 7 December 2012; revised 21 February 2013; accepted 22 February 2013; published online 19 March 2013

(c) 2013 Cancer Research UK. All rights reserved 0007-0920/13 
prognostic biomarker for CRC survival, independent of anti-EGFR therapy, is less clear.

A number of previous studies have evaluated the relationship between KRAS-mutation status and survival after CRC diagnosis (Andreyev et al, 1998; Samowitz et al, 2000; Andreyev et al, 2001; Gnanasampanthan et al, 2001; Wang et al, 2003; Lee et al, 2008; Ogino et al, 2009a; Nash et al, 2010; Roth et al, 2010; De Roock et al, 2010a; Hutchins et al, 2011; Imamura et al, 2012). In the largest study to date, Andreyev et al (2001) reported that the presence of a somatic KRAS mutation was associated with statistically significantly poorer disease-free and overall survival after CRC diagnosis, but only among patients with Dukes' C CRC and only among those with the KRAS p.G12V mutation (Andreyev et al, 2001). This latter finding was supported by results from a recent study in which KRAS codon 12 mutations, particularly the p.G12V mutation, but not KRAS codon 13 mutations were associated with poorer survival (Imamura et al, 2012). Thus, observed inconsistencies in the literature regarding the association between KRAS-mutation status and CRC survival may be related to differences in the distribution of specific KRAS mutations, stage at diagnosis, or other characteristics.

Correlations between KRAS-mutation status and other tumour characteristics of prognostic relevance may further complicate the study of this marker in relation to prognosis. In particular, KRASmutated CRC is less likely to exhibit microsatellite instability (MSI) than KRAS-wild-type CRCs (Ogino et al, 2009a; Nash et al, 2010; Roth et al, 2010; Hutchins et al, 2011; Imamura et al, 2012) and is almost never BRAF-mutated (Lee et al, 2008; De Roock et al, 2010a; Hutchins et al, 2011; Imamura et al, 2012). The presence of high MSI (MSI-H) is associated with a more favourable prognosis (Guastadisegni et al, 2010), whereas BRAF-mutated CRC has a poorer prognosis than $B R A F$-wild-type disease (Ogino et al, 2009b; Roth et al, 2010; De Roock et al, 2010a). Failure to account for these attributes of KRAS-mutated CRC could thus obscure an association between KRAS-mutation status and CRC survival.

To better understand the relationship between KRAS-mutation status and survival after CRC diagnosis, we used data from two concurrent population-based studies of incident invasive CRC conducted in Western Washington State.

\section{MATERIALS AND METHODS}

Study population. Details of the population-based study samples have been published elsewhere (Newcomb et al, 2007a, b). Briefly, eligible participants included men and women diagnosed with invasive CRC between January 1998 and June 2002 who, at the time of diagnosis, were aged 20-74 years and resided in King, Pierce, or Snohomish counties in Western Washington State. Women who resided in 10 additional Washington counties and were diagnosed during the same time period at ages $50-74$ years were also eligible. During a second phase of study recruitment, we identified eligible participants as men and women with invasive CRC in this 13-county ascertainment area who were diagnosed at ages 18-49 years between April 2002 and July 2007. All cases were identified through the Surveillance, Epidemiology, and End Results (SEER) cancer registry serving Western Washington State. Study eligibility was limited to English speakers with a publicly available telephone number. Of 3585 individuals contacted and identified as eligible, 463 (13\%) were deceased, 351 (10\%) refused participation, $128(4 \%)$ could not be reached, and $24(0.7 \%)$ completed only a partial interview. In total, $76 \%$ of eligible cases were enrolled in the study $(N=2708)$.

At an average of 8.6 months after diagnosis, participants completed a structured telephone interview in which they were asked to provide detailed information on a number of potential risk factors, including smoking history, body mass index (BMI), family history of CRC, and use of selected medications. At the conclusion of the interview, participants were asked for consent to access diagnostic tumour specimens. Adequate tumour specimens were obtained for $78 \%$ of enrolled participants $(N=2120)$.

This study was approved by the Institutional Review Board of the Fred Hutchinson Cancer Research Center in accordance with assurances filed with and approved by the US Department of Health and Human Services.

KRAS-mutation testing and additional tumour characterisation. DNA was extracted from paraffin-embedded formalin-fixed tumour tissue. In cases for whom tumour DNA was successfully extracted $(N=1989)$, the coding sequence of KRAS exon 2 was amplified (Oliner et al, 2010). Mutations in exon 2 were identified via forward and reverse sequencing of amplified tumour DNA (Alsop et al, 2006). Cases for whom KRAS testing failed $(N=36)$ or produced equivocal results $(N=30)$ were classified as having unknown KRAS-mutation status. For quality control purposes, sequencing was also conducted on three cell-line controls (one containing the p.G12V mutation, one containing the p.G13D mutation, and one wild-type cell line).

Tumour specimens were also assayed for BRAF-mutation status and for the presence of MSI. Tumour DNA was tested for the c.1799 T > A (p.V600E) BRAF mutation using a fluorescent allelespecific PCR assay as described previously (Buchanan et al, 2010). With respect to MSI status, testing for cases enrolled in earlier years of recruitment $(N=1430)$ was based on a 10 -gene panel assayed in tumour DNA and in DNA extracted from normal surrounding tissue (BAT25, BAT26, BAT40, MYCL, D5S346, D17S250, ACTC, D18S55, D10S197, and BAT34C4) (Boland et al, 1998; Newcomb et al, 2007b); tumours were classified as MSI-H if instability was observed in $\geqslant 30 \%$ of markers, and as MSS if instability was observed in $<30 \%$ of markers. For more recently enrolled cases $(N=470)$, MSI status was based on immunohistochemistry (IHC) testing of four markers: MLH1, MSH2, MSH6, and PMS2 (Lindor et al, 2002; Shia, 2008); cases whose tumour tissue exhibited positive staining for all markers were considered MSS, whereas cases negative for at least one marker were considered MSI-H. High concordance between IHC and PCRbased MSI testing has been demonstrated elsewhere (Cicek et al, 2011). Cases for whom test results were equivocal or for whom testing was not completed $(N=80)$ were classified as having unknown MSI status.

Information on tumour site and stage at diagnosis was available from SEER. Tumours located in the caecum through the splenic flexure were grouped together as proximal colon cancers (ICD-O-3 codes C180, C182, C183, C184, and C185) (World Health Organisation, 2000). Tumours located in the descending (C186) and sigmoid colon (C187) were classified as distal colon cancer, and tumours in the rectosigmoid junction (C199) and rectum (C209) were grouped together as rectal cancer. Stage at diagnosis was recorded according to SEER summary staging conventions (localised-, regional-, distant-stage).

Survival information. Vital status was determined via linkage to SEER and the National Death Index. For cases who died during study follow-up, information was obtained on the date and cause of death, classified according to ICD-10 conventions (World Health Organisation, 2007). Deaths with an underlying cause attributed to ICD-10 codes C18.0-C20.0 or C26.0 (that is, CRC) were classified as disease-specific mortality events. Vital-status linkage was performed periodically, with the most recent linkage capturing deaths occurring through September 2010.

Statistical analysis. We used Cox proportional hazards regression to evaluate the association between KRAS-mutation status and survival after CRC diagnosis. The time axis for analysis was defined 
as days since diagnosis, with left censoring of participants until the date of study enrollment. We conducted separate survival analyses for disease-specific survival and overall survival. In all analyses, participants still alive at their last vital-status assessment were censored at that date. In analyses of disease-specific survival, we also censored persons who died due to causes other than CRC at the time of death. We evaluated associations between KRASmutation status and survival outcomes in the full cohort and within strata defined by patient characteristics (age at diagnosis, sex) and tumour characteristics (tumour site, stage, MSI status). In light of the fact that somatic mutations in KRAS and BRAF rarely co-occur (Davies et al, 2002), and given that BRAF-mutated CRC has been shown to have a poorer prognosis than $B R A F$-wild-type CRC (Ogino et al, 2009b; Roth et al, 2010; De Roock et al, 2010a), we conducted separate analyses: (1) in all cases irrespective of $B R A F$-mutation status; (2) restricted to $B R A F$-wild-type cases; and (3) combining information on KRAS and BRAF mutations to evaluate relative differences in survival for cases with a mutation in either $v s$ neither gene. We also evaluated relative differences in survival between case groups defined by joint KRAS/MSI status, and by joint KRAS/BRAF/MSI status. Finally, we explored associations between different classes of KRAS mutations and survival outcomes, examining associations with specific mutations evident in $\geqslant 5 \%$ of cases, and, more generally, with codon 12 mutations and codon 13 mutations separately; differences in codon-specific associations were evaluated via tests for heterogeneity. For all analyses, proportional hazards assumptions were assessed by testing for a non-zero slope of the scaled Schoenfeld residuals on ranked failure times (Therneau and Grambsch, 2000).

Regression models included adjustment terms for age (5-year categories), sex, and study phase. We also assessed potential confounding by several patient and tumour characteristics: cigarette smoking (never, former, current); BMI 2 years before diagnosis $\left(<25.0,25.0-29.9, \geqslant 30.0 \mathrm{~kg} \mathrm{~m}^{-2}\right)$; race (white, nonwhite); regular use of non-steroidal anti-inflammatory drugs at baseline (no, yes); family history of CRC in first-degree relatives (no, yes); and tumour site (proximal colon, distal colon/rectum). Of these additional factors, only cigarette smoking and BMI were retained in our final analytic model as adjustment for other variables had minimal impact on effect estimates ( $<5 \%$ change).

We conducted sensitivity analyses using alternative approaches to assess the potential impact of excluding enrolled cases with unknown KRAS-mutation status. Specifically, we replicated analyses: (1) including all cases with missing KRAS-mutation status as KRAS wild-type; (2) including cases with missing KRASmutation status as KRAS-mutated; and (3) using multiple imputation for missing KRAS status. The multiple imputation model was based on all covariate variables from the multivariate model, as well as family history of CRC, tumour site, MSI status, $B R A F$-mutation status, race, survival time, and the survival outcome of interest (Moons et al, 2006; Sterne et al, 2009). All analyses were conducted in STATA SE version 12.0 (College Park, TX, USA).

\section{RESULTS}

Characteristics of the study population are presented in Table 1 by KRAS-mutation status. Approximately $31 \%$ of cases had KRASmutated CRC. Compared with cases with KRAS-wild-type CRC, cases with $K R A S$-mutated disease were statistically significantly less likely to have MSI-H or BRAF-mutated CRC $(P$-value $<0.001)$. There was no statistically significant difference in the distribution of age at diagnosis, sex, tumour site, or stage according to KRASmutation status. Overall, $38 \%(N=728)$ of cases died during the study follow-up period $($ mean $=6.5$ years, range $=5.3$ months

\begin{tabular}{|c|c|c|c|}
\hline & $\begin{array}{l}\text { KRAS wild-type } \\
\quad(N=1330)\end{array}$ & $\begin{array}{l}\text { KRAS-mutated } \\
\quad(N=593)\end{array}$ & $P$-value* \\
\hline \multicolumn{4}{|c|}{ Age at diagnosis } \\
\hline $\begin{array}{l}<50 \\
50-59 \\
60-69 \\
70-74\end{array}$ & $\begin{array}{l}346(26) \\
291(22) \\
415(31) \\
278(21)\end{array}$ & $\begin{array}{l}147(25) \\
143(24) \\
188(32) \\
115(19)\end{array}$ & 0.65 \\
\hline \multicolumn{4}{|l|}{ Sex } \\
\hline $\begin{array}{l}\text { Male } \\
\text { Female }\end{array}$ & $\begin{array}{l}609(46) \\
721(54)\end{array}$ & $\begin{array}{l}264(45) \\
329(55)\end{array}$ & 0.61 \\
\hline \multicolumn{4}{|l|}{ Tumour site } \\
\hline $\begin{array}{l}\text { Proximal colon } \\
\text { Distal colon } \\
\text { Rectal } \\
\text { Unknown }\end{array}$ & $\begin{array}{c}505(39) \\
364(28) \\
424(33) \\
37\end{array}$ & $\begin{array}{c}255(44) \\
147(25) \\
183(31) \\
89\end{array}$ & 0.10 \\
\hline \multicolumn{4}{|c|}{ Stage at diagnosis ${ }^{a}$} \\
\hline $\begin{array}{l}\text { Localised } \\
\text { Regional } \\
\text { Distant } \\
\text { Unknown }\end{array}$ & $\begin{array}{c}553(42) \\
610(46) \\
144(11) \\
23\end{array}$ & $\begin{array}{c}220(37) \\
293(50) \\
75(13) \\
5\end{array}$ & 0.12 \\
\hline \multicolumn{4}{|l|}{ MSI status ${ }^{a}$} \\
\hline $\begin{array}{l}\text { MSS/MSI-L } \\
\text { MSI-H } \\
\text { Unknown }\end{array}$ & $\begin{array}{l}1042(82) \\
236(18) \\
52\end{array}$ & $\begin{array}{c}509(90) \\
56(10) \\
28\end{array}$ & $<0.001$ \\
\hline \multicolumn{4}{|c|}{ BRAF mutation status ${ }^{a}$} \\
\hline $\begin{array}{l}\text { Wild-type } \\
\text { Mutated } \\
\text { Unknown }\end{array}$ & $\begin{array}{c}1083(82) \\
232(18) \\
15\end{array}$ & $\begin{array}{c}580(99) \\
6(1) \\
7\end{array}$ & $<0.001$ \\
\hline \multicolumn{4}{|l|}{ Vital status } \\
\hline $\begin{array}{l}\text { Alive } \\
\text { Deceased }\end{array}$ & $\begin{array}{l}843(63) \\
487(37)\end{array}$ & $\begin{array}{l}352(59) \\
241(41)\end{array}$ & 0.09 \\
\hline $\begin{array}{l}\text { Mean years of } \\
\text { follow-up (s.d.) }\end{array}$ & $6.7(3.9)$ & $6.3(4.1)$ & \\
\hline \multicolumn{4}{|c|}{$\begin{array}{l}\text { Abbreviations: } K R A S=\text { Kirsten Ras; } M S I=\text { microsatellite instability; MSI-H = high micro- } \\
\text { satellite instability. }{ }^{*} \text {-value for } \chi^{2} \text {. } \\
\mathrm{a}_{\%} \text { distribution excludes cases with unknown value of characteristic. }\end{array}$} \\
\hline
\end{tabular}

to 13.7 years). Of those cases who died, $\sim 62 \%(N=449)$ died because of CRC.

Multivariate-adjusted analyses of disease-specific survival yielded estimates nearly identical to those from unadjusted analyses, and provided evidence of statistically significantly poorer survival in cases with KRAS-mutated vs KRAS-wild-type CRC (Table 2) (hazard ratio $(\mathrm{HR})=1.37,95 \%$ confidence interval (CI): 1.13-1.66). The magnitude of this association was similar when cases with $B R A F$-mutated disease were excluded or combined with the KRAS-mutated case group. Interaction terms by age at diagnosis, sex, tumour site, stage, and MSI status were not statistically significant $(P>0.05)$; however, point estimates did vary slightly by stage and age at diagnosis. In particular, KRAS-mutation status was not associated with survival in cases who presented with distant-stage disease $(P$-interaction by stage $=0.07)$. Additionally, KRAS-mutated CRC was associated with statistically significantly poorer disease-specific survival in cases aged $\geqslant 50$ years at diagnosis but not in those aged $<50$ ( $P$-interaction by age $=0.15)$. 
Table 2. KRAS-mutation status and disease-specific survival after colorectal cancer diagnosis by patient and tumour characteristics, with and without consideration of BRAF-mutation status

\begin{tabular}{|c|c|c|c|c|c|c|c|c|c|}
\hline & \multicolumn{3}{|c|}{ All cases } & \multicolumn{3}{|c|}{ BRAF-wild-type CRC only } & \multicolumn{3}{|c|}{ Joint $K R A S / B R A F$ mutation status } \\
\hline & $\begin{array}{c}\text { KRAS- } \\
\text { wild-type } \\
\text { deaths/ } \\
\text { cases }\end{array}$ & $\begin{array}{c}\text { KRAS- } \\
\text { mutated } \\
\text { deaths/ } \\
\text { cases }\end{array}$ & $\mathrm{HR}(95 \% \mathrm{Cl})^{\mathrm{a}}$ & $\begin{array}{l}\text { KRAS- } \\
\text { wild-type } \\
\text { deaths/ } \\
\text { cases }\end{array}$ & $\begin{array}{c}\text { KRAS- } \\
\text { mutated } \\
\text { deaths/ } \\
\text { cases }\end{array}$ & $\mathrm{HR}(95 \% \mathrm{Cl})^{\mathrm{a}}$ & $\begin{array}{c}\text { KRAS- and } \\
\text { BRAF-wt } \\
\text { deaths/ } \\
\text { cases }\end{array}$ & $\begin{array}{c}\text { KRAS- or } \\
\text { BRAF-mut } \\
\text { deaths/ } \\
\text { cases }\end{array}$ & $\mathrm{HR}(95 \% \mathrm{Cl})^{\mathrm{a}}$ \\
\hline $\begin{array}{l}\text { Overall } \\
\text { (unadjusted) }\end{array}$ & $287 / 1330$ & $162 / 593$ & $1.36(1.12-1.65)$ & $238 / 1098$ & $161 / 587$ & $1.39(1.14-1.70)$ & $234 / 1083$ & $214 / 834$ & $1.31(1.09-1.58)$ \\
\hline $\begin{array}{l}\text { Overall } \\
\text { (adjusted) }\end{array}$ & $287 / 1330$ & $162 / 593$ & $1.37(1.13-1.66)$ & $238 / 1098$ & $161 / 587$ & $1.40(1.14-1.72)$ & $234 / 1083$ & $214 / 834$ & $1.34(1.11-1.63)$ \\
\hline \multicolumn{10}{|c|}{ By age at diagnosis } \\
\hline $\begin{array}{l}<50 \text { years } \\
\geqslant 50 \text { years }\end{array}$ & $\begin{array}{l}\text { 79/346 } \\
\text { 208/984 }\end{array}$ & $\begin{array}{l}34 / 147 \\
128 / 446\end{array}$ & $\begin{array}{l}1.03(0.69-1.54) \\
1.48(1.18-1.85)\end{array}$ & \begin{tabular}{|l|}
$67 / 320$ \\
$171 / 778$
\end{tabular} & $\begin{array}{l}34 / 147 \\
127 / 440\end{array}$ & $\begin{array}{l}1.14(0.76-1.73) \\
1.49(1.18-1.88)\end{array}$ & $\begin{array}{l}65 / 317 \\
169 / 766\end{array}$ & $\begin{array}{l}48 / 176 \\
166 / 658\end{array}$ & $\begin{array}{l}1.40(0.96-2.03) \\
1.33(1.07-1.66)\end{array}$ \\
\hline \multicolumn{10}{|l|}{ By sex } \\
\hline $\begin{array}{l}\text { Male } \\
\text { Female }\end{array}$ & $\begin{array}{l}134 / 609 \\
153 / 721\end{array}$ & $\begin{array}{l}74 / 264 \\
88 / 329\end{array}$ & $\begin{array}{l}1.35(1.02-1.79) \\
1.38(1.06-1.81)\end{array}$ & $\begin{array}{l}119 / 545 \\
119 / 553\end{array}$ & $\begin{array}{l}73 / 261 \\
88 / 326\end{array}$ & $\begin{array}{l}1.37(1.03-1.85) \\
1.43(1.07-1.89)\end{array}$ & $\begin{array}{l}118 / 542 \\
116 / 541\end{array}$ & \begin{tabular}{|l|}
$89 / 329$ \\
$125 / 505$
\end{tabular} & $\begin{array}{l}1.36(1.03-1.79) \\
1.35(1.04-1.75)\end{array}$ \\
\hline \multicolumn{10}{|c|}{ By tumour site } \\
\hline $\begin{array}{l}\text { Proximal } \\
\text { Distal/rectal }\end{array}$ & $\begin{array}{l}104 / 505 \\
178 / 788\end{array}$ & $\begin{array}{l}72 / 255 \\
87 / 330\end{array}$ & $\begin{array}{l}1.44(1.06-1.95) \\
1.29(1.00-1.68)\end{array}$ & \begin{tabular}{|l|}
$68 / 322$ \\
$166 / 745$
\end{tabular} & $\begin{array}{l}71 / 252 \\
87 / 327\end{array}$ & $\begin{array}{l}1.45(1.04-2.04) \\
1.33(1.02-1.73)\end{array}$ & $\begin{array}{l}67 / 315 \\
163 / 737\end{array}$ & \begin{tabular}{|l}
$109 / 444$ \\
$101 / 376$
\end{tabular} & $\begin{array}{l}1.25(0.92-1.71) \\
1.35(1.04-1.73)\end{array}$ \\
\hline \multicolumn{10}{|c|}{ By stage at diagnosis } \\
\hline $\begin{array}{l}\text { Localised } \\
\text { Regional } \\
\text { Distant }\end{array}$ & $\begin{array}{l}29 / 553 \\
146 / 610 \\
111 / 144\end{array}$ & $\begin{array}{l}19 / 220 \\
83 / 293 \\
59 / 75\end{array}$ & $\begin{array}{l}1.55(0.85-2.82) \\
1.35(1.03-1.78) \\
1.02(0.73-1.41)\end{array}$ & $\begin{array}{l}28 / 463 \\
111 / 487 \\
98 / 129\end{array}$ & $\begin{array}{l}19 / 216 \\
82 / 291 \\
59 / 75\end{array}$ & $\begin{array}{l}1.38(0.75-2.54) \\
1.47(1.10-1.96) \\
1.06(0.76-1.49)\end{array}$ & $\begin{array}{l}28 / 458 \\
109 / 480 \\
96 / 126\end{array}$ & $\begin{array}{l}20 / 311 \\
121 / 424 \\
72 / 90\end{array}$ & $\begin{array}{l}1.06(0.58-1.93) \\
1.50(1.15-1.96) \\
1.11(0.80-1.53)\end{array}$ \\
\hline \multicolumn{10}{|l|}{ By MSI } \\
\hline $\begin{array}{l}\text { MSS } \\
\text { MSI-H }\end{array}$ & $\begin{array}{l}257 / 1042 \\
22 / 236\end{array}$ & $\begin{array}{l}143 / 509 \\
11 / 56\end{array}$ & $\begin{array}{l}1.24(1.00-1.52) \\
2.06(0.93-4.52)\end{array}$ & $\begin{array}{l}221 / 943 \\
10 / 115\end{array}$ & $\begin{array}{l}142 / 504 \\
11 / 55\end{array}$ & $\begin{array}{l}1.33(1.07-1.65) \\
2.17(0.89-5.31)\end{array}$ & $\begin{array}{l}217 / 933 \\
10 / 112\end{array}$ & $\begin{array}{l}180 / 613 \\
25 / 181\end{array}$ & $\begin{array}{l}1.40(1.15-1.72) \\
1.67(0.77-3.61)\end{array}$ \\
\hline
\end{tabular}

These non-significant differences in the strength of association across stage and age strata were diminished in analyses combining cases with BRAF-mutated and KRAS-mutated CRC. Associations were similar but attenuated in analyses of overall survival (Table 3 ).

In analyses considering KRAS in combination with MSI status (Table 4), disease-specific and overall survival were statistically significantly more favourable in cases with KRAS-wild-type/ MSI-H CRC $(\mathrm{HR}=0.35,95 \% \mathrm{CI}: 0.23-0.55$, and $\mathrm{HR}=0.78,95 \%$ CI: $0.60-1.00$, respectively) and statistically significantly poorer in cases with KRAS-mutated/MSS CRC (HR $=1.24$, 95\% CI: $1.01-$ 1.52 , and $\mathrm{HR}=1.21,95 \% \mathrm{CI}: 1.02-1.43$, respectively) compared with cases with KRAS-wild-type/MSS disease. Results were similar after excluding cases with BRAF-mutated CRC. Patterns of association also changed very little when combining cases with KRAS- and/or BRAF-mutated disease: cases with KRAS- and $B R A F$-wild-type/MSI-H disease had the most favourable prognosis, and those with KRAS- or BRAF-mutated/MSS disease had the poorest survival.

Among cases with KRAS-mutated CRC, 75\% $\quad(N=444)$ had a mutation in codon 12 and $22 \%(N=132)$ in codon 13 (Supplementary Table 1). Compared with cases with a codon 12 KRAS mutation, those with a codon 13 mutation were statistically significantly more likely to have CRC located in the proximal colon (54\% vs 40\%) and to have MSI-H disease (19\% vs $7 \%)$. We found no statistically significant differences in the association between KRAS-mutation status and survival when we evaluated associations with mutated codon 12 vs mutated codon $13(P$-heterogeneity $=0.54$ and $P$-heterogeneity $=0.30$ for diseasespecific and overall survival, respectively). The presence of a somatic p.G13D mutation was associated with statistically significantly poorer disease-specific $(\mathrm{HR}=1.48,95 \% \quad \mathrm{CI}$ : $1.04-2.04)$ and overall survival $(\mathrm{HR}=1.38,95 \% \mathrm{CI}$ : $1.05-1.81$ ) compared with KRAS-wild-type; neither p.G12D nor p.G12V mutations were significantly associated with survival outcomes when evaluated separately (Supplementary Table 2).

Compared with cases with known KRAS-mutation status, enrolled cases with unknown KRAS status were younger at diagnosis (median age $=52$ years $v s 60$ years), more likely to have distant-stage disease (20\% vs $12 \%)$, and had a lower 5-year overall survival (65\% vs 74\%) (not shown). In sensitivity analyses, we evaluated the effect of missing information on KRAS status $(N=728,29 \%)$. In analyses based on our primary analytic model with no exclusion of $B R A F$-mutated cases, including all cases with unknown KRAS-mutation status as KRAS-mutated cases increased point estimates to $\mathrm{HR}=1.53$ (95\% CI: $1.13-1.79$ ) for diseasespecific survival and $\mathrm{HR}=1.39$ (95\% CI: $1.23-1.57$ ) for overall survival. When we instead included these 728 cases as KRAS-wildtype, point estimates fell to $\mathrm{HR}=1.12$ (95\% CI: $0.94-1.34$ ) and $\mathrm{HR}=1.06$ (95\% CI: $0.92-1.23)$ for disease-specific and overall survival, respectively. Thus, our point estimates comparing survival in KRAS-mutated vs KRAS-wild-type cases are subject to some uncertainty due to the exclusion of cases with missing KRAS data. 


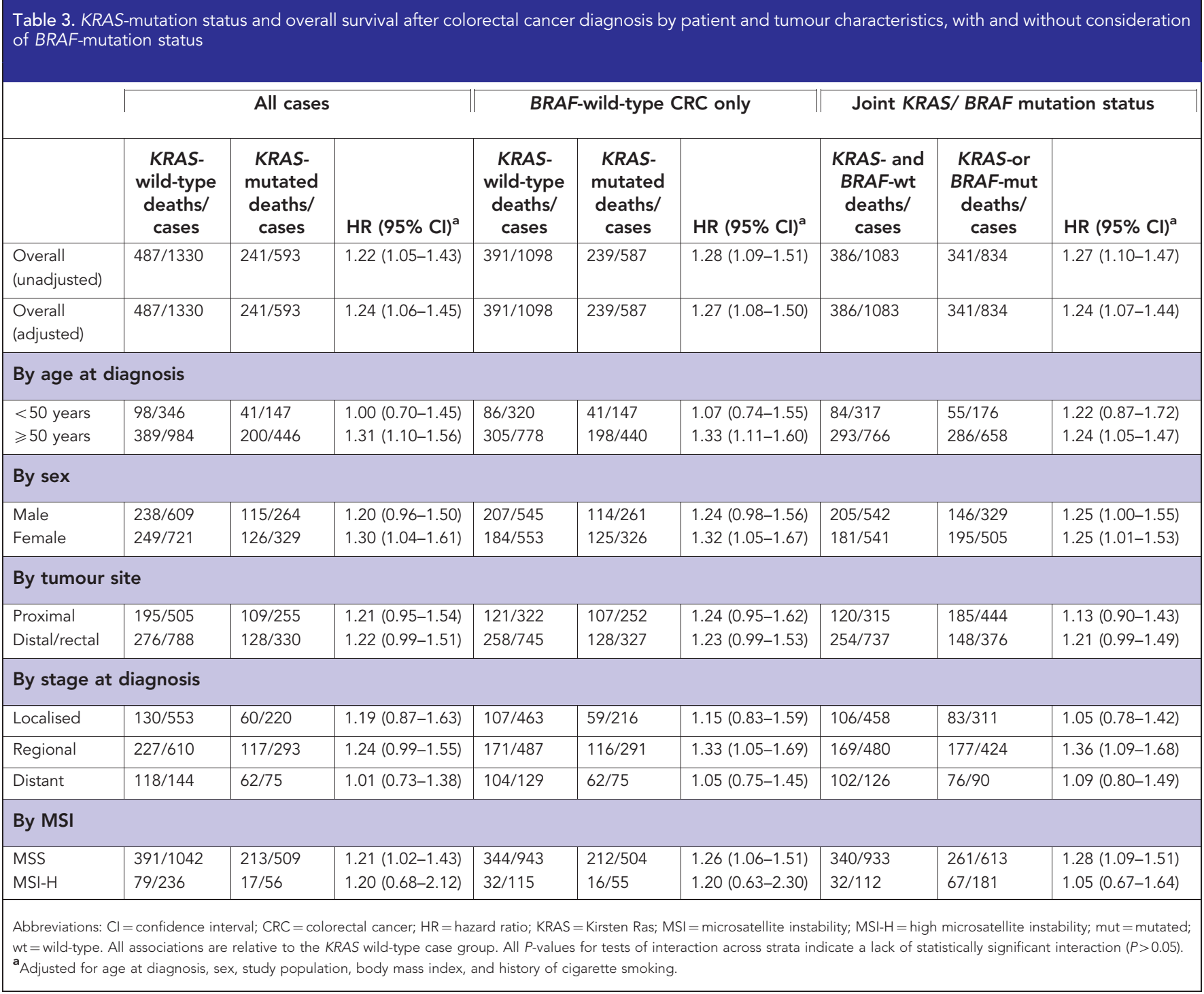

However, when we implemented a multiple imputation model to account for missingness in KRAS, our results based on the analysis of known and imputed KRAS data indicated statistically significantly poorer disease-specific ( $\mathrm{HR}=1.35,95 \% \mathrm{CI}: 1.12-1.63)$ and overall survival $(\mathrm{HR}=1.22,95 \% \mathrm{CI}$ : $1.05-1.42)$ associated with the presence of a KRAS mutation.

\section{DISCUSSION}

In this large population-based cohort of men and women with incident invasive CRC, the presence of a somatic KRAS mutation was associated with statistically significantly poorer survival, specifically in those without distant-stage disease. Patients with KRAS-mutated CRC, whose tumours were also MSS, had the poorest prognosis. These patterns of association were relatively unchanged when limited to $B R A F$-wild-type cases and when grouping BRAF-mutated and KRAS-mutated cases. Contrary to some previous reports, we did not find the association between KRAS-mutation status and survival to be limited to the p.G12V KRAS-mutation specific identified mutations.

Activating mutations in KRAS are among the most common mutations in human cancers (Ikediobi et al, 2006). Mutations in KRAS codons 12 and 13 have been shown to result in an altered RAS protein with greater resistance to GTPase activity (Bollag and
McCormick, 1995; Al-Mulla et al, 1999). By remaining in an active GTP-bound state for longer, mutated RAS contributes to enhanced cellular growth and proliferation (Al-Mulla et al, 1999), activating the RAS/RAF/MAPK and the phosphoinositide 3-kinase-AKT pathways. The relationship between constitutive activation of the RAS/RAF/MAPK signalling pathway and CRC prognosis has previously also been supported by studies evaluating the association between the BRAF p.V600E activating mutation and CRC survival (Ogino et al, 2009b; Roth et al, 2010; De Roock et al, 2010a). Mutations in BRAF and KRAS are both thought to occur early in colorectal carcinogenesis, and are rarely observed together. Here, we found that only $1 \%(N=6)$ of CRC cases with a somatic KRAS mutation harboured a BRAF mutation, compared with $18 \%$ of KRAS-wild-type CRC cases; this is consistent with data from The Cancer Genome Atlas (Cerami et al, 2012) and recent reports from other large studies (Hutchins et al, 2011; Imamura et al, 2012). When we combined information on KRAS and BRAF status to compare survival in CRC cases with a somatic mutation in at least one $v s$ neither of these genes, we found only modest differences from our analyses where $B R A F$-mutation status was not considered.

The presence of a somatic KRAS mutation is also inversely associated with the presence of MSI (Ogino et al, 2009a; Nash et al, 2010; Imamura et al, 2012). MSI-H CRC is known to have a statistically significantly more favourable prognosis than MSS CRC (Guastadisegni et al, 2010), and to have a distinct 


\begin{tabular}{|c|c|c|c|c|}
\hline & \multicolumn{2}{|c|}{ Disease-specific survival } & \multicolumn{2}{|c|}{ Overall survival } \\
\hline & Deaths/cases & $\operatorname{HR}(95 \% \mathrm{Cl})^{\mathrm{a}}$ & Deaths/cases & $\operatorname{HR}(95 \% \mathrm{Cl})^{a}$ \\
\hline \multicolumn{5}{|c|}{ Joint KRAS and MSI status } \\
\hline $\begin{array}{l}\text { KRAS wt/MSI-H } \\
\text { KRAS mut/MSI-H } \\
\text { KRAS wt/MSS } \\
\text { KRAS mut/MSS }\end{array}$ & $\begin{array}{c}22 / 236 \\
11 / 56 \\
257 / 1042 \\
143 / 509\end{array}$ & $\begin{array}{c}0.35(0.23-0.55) \\
0.77(0.42-1.41) \\
1.00 \text { (ref) } \\
1.24(1.01-1.52)\end{array}$ & $\begin{array}{c}79 / 236 \\
17 / 56 \\
391 / 1042 \\
213 / 509\end{array}$ & $\begin{array}{c}0.78(0.60-1.00) \\
0.87(0.53-1.42) \\
1.00 \text { (ref) } \\
1.21(1.02-1.43)\end{array}$ \\
\hline \multicolumn{5}{|c|}{ Joint KRAS and MSI status (BRAF wild-type only) } \\
\hline $\begin{array}{l}\text { KRAS wt/MSI-H } \\
\text { KRAS mut/MSI-H } \\
\text { KRAS wt/MSS } \\
\text { KRAS mut/MSS }\end{array}$ & $\begin{array}{c}10 / 112 \\
11 / 53 \\
217 / 933 \\
141 / 501\end{array}$ & $\begin{array}{c}0.34(0.18-0.65) \\
0.87(0.47-1.60) \\
1.00 \text { (ref) } \\
1.36(1.09-1.68)\end{array}$ & $\begin{array}{c}32 / 112 \\
16 / 53 \\
340 / 933 \\
210 / 501\end{array}$ & $\begin{array}{c}0.74(0.51-1.07) \\
0.92(0.55-1.52) \\
1.00 \text { (ref) } \\
1.27(1.07-1.52)\end{array}$ \\
\hline \multicolumn{5}{|c|}{ Joint KRAS, BRAF, and MSI status } \\
\hline $\begin{array}{l}\text { KRAS and BRAF wt/MSI-H } \\
\text { KRAS or BRAF mut/MSI-H } \\
\text { KRAS and BRAF wt/MSS } \\
\text { KRAS or BRAF mut/MSS }\end{array}$ & $\begin{array}{l}10 / 112 \\
25 / 181 \\
217 / 933 \\
180 / 613\end{array}$ & $\begin{array}{c}0.34(0.18-0.65) \\
0.60(0.39-0.91) \\
1.00(\text { ref }) \\
1.41(1.15-1.73)\end{array}$ & $\begin{array}{c}32 / 112 \\
67 / 181 \\
340 / 933 \\
261 / 613\end{array}$ & $\begin{array}{c}0.75(0.52-1.08) \\
0.91(0.69-1.20) \\
1.00 \text { (ref) } \\
1.28(1.08-1.51)\end{array}$ \\
\hline
\end{tabular}

clinicopathology: the distribution of MSI follows a clear gradient of decreasing prevalence from the ascending colon to the rectum (Yamauchi et al, 2012) and is less prevalent in cases diagnosed at later stages (Ogino et al, 2009b; Nash et al, 2010). Although we found that the prevalence of MSI was statistically significantly lower in KRAS-mutated vs KRAS-wild-type cases, we found no difference in the distribution of tumour site or stage at diagnosis according to KRAS status. We also found no statistically significant interaction in the association between KRAS-mutation status and survival according to MSI status, tumour site, or stage at diagnosis. However, our results did suggest that KRAS-mutation status was not associated with survival in cases who presented with distantstage disease, as has been suggested by at least two previous studies (Nash et al, 2010; Inoue et al, 2012). Thus, although the prevalence of somatic KRAS mutations does not appear to differ by stage at diagnosis, the prognostic role of KRAS may differ by stage.

Several studies in the distant-stage, metastatic setting have demonstrated the utility of KRAS-mutation status as a predictive marker for response to anti-EGFR therapy (Lin et al, 2011; Bokemeyer et al, 2012). In a recent meta-analysis, Lin et al (2011) reported that the presence of a KRAS mutation had a positive likelihood ratio of 2.0 (95\% CI: 1.45-2.76) for predicting nonresponse to anti-EGFR in distant-stage CRC . However, the role of $K R A S$ as a predictive marker has not been demonstrated for less advanced disease: recently published findings from a phase III randomized trial of patients with stage III colon cancer indicated no benefit in 3-year disease-free survival with the addition of cetuximab to standard chemotherapy, regardless of KRAS-mutation status ( $\mathrm{HR}=1.21,95 \% \mathrm{CI}$ : $0.98-1.49$ in KRAS-wild-type and $\mathrm{HR}=1.12,95 \% \mathrm{CI}: 0.86-1.46$ in KRAS mutated) (Alberts et al, 2012). Results from that trial did, however, provide support for the role of KRAS-mutation status as a prognostic factor, independent of anti-EGFR therapy: 3-year disease-free survival ranged from $72-75 \%$ across treatment arms in participants with KRAS-wildtype disease $v s 65-67 \%$ in participants with KRAS-mutated disease (Alberts et al, 2012).
Previous studies focused on KRAS-mutation status as a potential prognostic factor has been mixed in their findings. In the largest study of KRAS-mutation status and survival to date, the Kirsten Ras Colorectal Cancer Collaborative Group study (RASCAL, $N=2721$ ), Andreyev et al (1998) reported statistically significantly poorer overall survival for KRAS-mutated vs KRAS-wild-type disease at a magnitude similar to that observed here $(H R=1.22$, 95\% CI: 1.07-1.40). The majority of other, smaller studies have also indicated a poorer prognosis in patients with KRAS-mutated CRC (Nash et al, 2010; De Roock et al, 2010a; Hutchins et al, 2011; Imamura et al, 2012). Several studies, however, have failed to find an association between KRAS and patient outcomes (Samowitz et al, 2000; Gnanasampanthan et al, 2001; Wang et al, 2003; Lee et al, 2008; Ogino et al, 2009a,b; Roth et al, 2010). The basis for these inconsistencies is unclear, but may be related to limited sample size and differences in the distribution and consideration of other factors, such as age at diagnosis, stage, and MSI status.

Prior studies have also differed in their consideration of specific KRAS mutations in relation to CRC survival. In an update of the original RASCAL study (RASCAL II, $N=4268$ ), Andreyev et al (2001) found the association between KRAS-mutation status and survival was largely confined to the p.G12V mutation. Imamura et al (2012) recently reported a similar finding, and found that mutations in KRAS codon 13 were not associated with CRC survival. Unlike these reports, we did not find a statistically significant association between the p.G12V KRAS mutation and prognosis. Although experimental evidence has suggested that mutations in KRAS codon 12, particularly p.G12V, confer lower GTPase activity (Bollag and McCormick, 1995; Al-Mulla et al, 1999), which may translate to greater transforming potential, our data are not consistent with a clear difference in the prognostic significance of somatic KRAS mutations by codon.

Results presented here should be interpreted in the context of study limitations. Only limited information on first course of treatment was available and it is possible that treatment could have differed according to KRAS-mutation status; however, 95\% of cases 
were diagnosed before 2006 at a time before KRAS-mutation status might have been used to decide on anti-EGFR therapy. KRASmutation status does not appear to be associated with differential response to other chemotherapies (Richman et al, 2009; Ogino et al, 2009a; Hutchins et al, 2011). In addition, KRAS-mutation status was not determined for $29 \%$ of enrolled cases. Although these cases differed from cases with known KRAS-mutation status on several factors that could be related to prognosis, we obtained point estimates similar to those in our primary analyses in sensitivity analyses using multiple imputation to account for these missing data. KRAS-mutation status also could not be determined in cases who were not enrolled in the present study because of refusal, death before enrollment, or loss to follow-up. If KRASmutated CRC is truly associated with poorer prognosis, the prevalence of KRAS mutations is likely to have been higher in those cases who died before they could be enrolled in the study: exclusion of deceased cases would thus have attenuated, rather than inflated our estimates of the strength of association.

Important strengths of the present study include the population-based design and large sample size. Our consideration of both MSI and BRAF-mutation status in evaluating the relationship between KRAS-mutation status and CRC survival also represents an important strength. Here, we confirm previous reports that KRAS-mutated CRC is less likely to be MSI-H and is very rarely $B R A F$ mutated. When we evaluated these three markers in combination in relation to survival, we found a strong gradient in risk, particularly with respect to disease-specific survival. Those individuals with CRC that was KRAS-wild-type, $B R A F$-wild-type, and MSI-H had the most favourable disease-specific survival; individuals with CRC that was KRAS- or BRAF-mutated and MSS experienced a statistically significantly poorer prognosis than other case groups defined by combinations of these three markers. These results support the prognostic significance of KRAS-mutation status beyond its now established role as a predictive marker in distant-stage CRC.

\section{ACKNOWLEDGEMENTS}

This work was supported by the National Cancer Institute, National Institutes of Health under RFA no. CA-95-011, and through cooperative agreements with members of the Colon Cancer Family Registry and Principal Investigators. In particular, this work was conducted through the Seattle Colorectal Cancer Family Registry (U01 CA074794) and through NCI grant R01CA076366. Paraffin-embedded tumour tissue for the Seattle Colorectal Cancer Family Registry was provided by The Jeremy Jass Memorial Pathology Bank. This publication was also supported by the NCI training grant R25CA94880 and by NCI grants K05CA152715 and K07CA172298. The content of this manuscript does not necessarily reflect the views or policies of the National Cancer Institute, nor does mention of trade names, commercial products, or organisations imply endorsement by the US Government or the Cancer Family Registry.

\section{REFERENCES}

Al-Mulla F, Milner-White EJ, Going JJ, Birnie GD (1999) Structural differences between valine- 12 and aspartate-12 Ras proteins may modify carcinoma aggression. J Pathol 187(4): 433-438.

Alberts SR, Sargent DJ, Nair S, Mahoney MR, Mooney M, Thibodeau SN, Smyrk TC, Sinicrope FA, Chan E, Gill S, Kahlenberg MS, Shields AF, Quesenberry JT, Webb TA, Farr Jr GH, Pockaj BA, Grothey A, Goldberg RM (2012) Effect of oxaliplatin, fluorouracil, and leucovorin with or without cetuximab on survival among patients with resected stage III colon cancer: a randomized trial. JAMA 307(13): 1383-1393.
Allegra CJ, Jessup JM, Somerfield MR, Hamilton SR, Hammond EH, Hayes DF, McAllister PK, Morton RF, Schilsky RL (2009) American Society of Clinical Oncology provisional clinical opinion: testing for KRAS gene mutations in patients with metastatic colorectal carcinoma to predict response to anti-epidermal growth factor receptor monoclonal antibody therapy. J Clin Oncol 27(12): 2091-2096.

Alsop K, Mead L, Smith LD, Royce SG, Tesoriero AA, Young JP, Haydon A, Grubb G, Giles GG, Jenkins MA, Hopper JL, Southey MC (2006) Low somatic K-ras mutation frequency in colorectal cancer diagnosed under the age of 45 years. Eur J Cancer 42(10): 1357-1361.

Andreyev HJ, Norman AR, Cunningham D, Oates JR, Clarke PA (1998) Kirsten ras mutations in patients with colorectal cancer: the multicenter "RASCAL" study. J Natl Cancer Inst 90(9): 675-684.

Andreyev HJ, Norman AR, Cunningham D, Oates J, Dix BR, Iacopetta BJ, Young J, Walsh T, Ward R, Hawkins N, Beranek M, Jandik P, Benamouzig R, Jullian E, Laurent-Puig P, Olschwang S, Muller O, Hoffmann I, Rabes HM, Zietz C, Troungos C, Valavanis C, Yuen ST, Ho JW, Croke CT, O'Donoghue DP, Giaretti W, Rapallo A, Russo A, Bazan V, Tanaka M, Omura K, Azuma T, Ohkusa T, Fujimori T, Ono Y, Pauly M, Faber C, Glaesener R, de Goeij AF, Arends JW, Andersen SN, Lovig T, Breivik J, Gaudernack G, Clausen OP, De Angelis PD, Meling GI, Rognum TO, Smith R, Goh HS, Font A, Rosell R, Sun XF, Zhang H, Benhattar J, Losi L, Lee JQ, Wang ST, Clarke PA, Bell S, Quirke P, Bubb VJ, Piris J, Cruickshank NR, Morton D, Fox JC, Al-Mulla F, Lees N, Hall CN, Snary D, Wilkinson K, Dillon D, Costa J, Pricolo VE, Finkelstein SD, Thebo JS, Senagore AJ, Halter SA, Wadler S, Malik S, Krtolica K, Urosevic N (2001) Kirsten ras mutations in patients with colorectal cancer: the 'RASCAL II' study. Br J Cancer 85(5): 692-696.

Bokemeyer C, Cutsem EV, Rougier P, Ciardiello F, Heeger S, Schlichting M, Celik I, Kohne CH (2012) Addition of cetuximab to chemotherapy as first-line treatment for KRAS wild-type metastatic colorectal cancer: Pooled analysis of the CRYSTAL and OPUS randomised clinical trials. Eur J Cancer 48(10): 1466-1475.

Boland CR, Thibodeau SN, Hamilton SR, Sidransky D, Eshleman JR, Burt RW, Meltzer SJ, Rodriguez-Bigas MA, Fodde R, Ranzani GN, Srivastava S (1998) A National Cancer Institute Workshop on microsatellite instability for cancer detection and familial predisposition: development of international criteria for the determination of microsatellite instability in colorectal cancer. Cancer Res 58(22): 5248-5257.

Bollag G, McCormick F (1995) Intrinsic and GTPase-activating proteinstimulated Ras GTPase assays. Methods Enzymol 255: 161-170.

Buchanan DD, Sweet K, Drini M, Jenkins MA, Win AK, English DR, Walsh MD, Clendenning M, McKeone DM, Walters RJ, Roberts A, Pearson SA, Pavluk E, Hopper JL, Gattas MR, Goldblatt J, George J, Suthers GK, Phillips KD, Woodall S, Arnold J, Tucker K, Muir A, Field M, Greening S, Gallinger S, Perrier R, Baron JA, Potter JD, Haile R, Frankel W, de la Chapelle A, Macrae F, Rosty C, Walker NI, Parry S, Young JP (2010) Risk factors for colorectal cancer in patients with multiple serrated polyps: a cross-sectional case series from genetics clinics. PLoS One 5(7): e11636.

Cerami E, Gao J, Dogrusoz U, Gross BE, Sumer SO, Aksoy BA, Jacobsen A, Byrne CJ, Heuer ML, Larsson E, Antipin Y, Reva B, Goldberg AP, Sander C, Schultz N (2012) The cBio cancer genomics portal: an open platform for exploring multidimensional cancer genomics data. Cancer Discovery 2(5): 401-404.

Cicek MS, Lindor NM, Gallinger S, Bapat B, Hopper JL, Jenkins MA, Young J, Buchanan D, Walsh MD, Le Marchand L, Burnett T, Newcomb PA, Grady WM, Haile RW, Casey G, Plummer SJ, Krumroy LA, Baron JA, Thibodeau SN (2011) Quality assessment and correlation of microsatellite instability and immunohistochemical markers among population- and clinic-based colorectal tumors results from the Colon Cancer Family Registry. J Mol Diagn 13(3): 271-281.

Davies H, Bignell GR, Cox C, Stephens P, Edkins S, Clegg S, Teague J, Woffendin H, Garnett MJ, Bottomley W, Davis N, Dicks E, Ewing R, Floyd Y, Gray K, Hall S, Hawes R, Hughes J, Kosmidou V, Menzies A, Mould C, Parker A, Stevens C, Watt S, Hooper S, Wilson R, Jayatilake H, Gusterson BA, Cooper C, Shipley J, Hargrave D, Pritchard-Jones K, Maitland N, Chenevix-Trench G, Riggins GJ, Bigner DD, Palmieri G, Cossu A, Flanagan A, Nicholson A, Ho JW, Leung SY, Yuen ST, Weber BL, Seigler HF, Darrow TL, Paterson H, Marais R, Marshall CJ, Wooster R, Stratton MR, Futreal PA (2002) Mutations of the BRAF gene in human cancer. Nature 417(6892): 949-954. 
De Roock W, Claes B, Bernasconi D, De Schutter J, Biesmans B, Fountzilas G, Kalogeras KT, Kotoula V, Papamichael D, Laurent-Puig P,

Penault-Llorca F, Rougier P, Vincenzi B, Santini D, Tonini G, Cappuzzo F, Frattini M, Molinari F, Saletti P, De Dosso S, Martini M, Bardelli A, Siena S, Sartore-Bianchi A, Tabernero J, Macarulla T, Di Fiore F, Gangloff AO, Ciardiello F, Pfeiffer P, Qvortrup C, Hansen TP, Van Cutsem E, Piessevaux H, Lambrechts D, Delorenzi M, Tejpar S (2010a) Effects of KRAS, BRAF, NRAS, and PIK3CA mutations on the efficacy of cetuximab plus chemotherapy in chemotherapy-refractory metastatic colorectal cancer: a retrospective consortium analysis. Lancet Oncol 11(8): 753-762.

De Roock W, Jonker DJ, Di Nicolantonio F, Sartore-Bianchi A, Tu D, Siena S, Lamba S, Arena S, Frattini M, Piessevaux H, Van Cutsem E, O'Callaghan CJ, Khambata-Ford S, Zalcberg JR, Simes J, Karapetis CS, Bardelli A, Tejpar S (2010b) Association of KRAS p.G13D mutation with outcome in patients with chemotherapy-refractory metastatic colorectal cancer treated with cetuximab. JAMA 304(16): 1812-1820.

Gnanasampanthan G, Elsaleh H, McCaul K, Iacopetta B (2001) Ki-ras mutation type and the survival benefit from adjuvant chemotherapy in Dukes' C colorectal cancer. J Pathol 195(5): 543-548.

Guastadisegni C, Colafranceschi M, Ottini L, Dogliotti E (2010) Microsatellite instability as a marker of prognosis and response to therapy: A metaanalysis of colorectal cancer survival data. Eur J Cancer 46(15): 2788-2798

Hutchins G, Southward K, Handley K, Magill L, Beaumont C, Stahlschmidt J, Richman S, Chambers P, Seymour M, Kerr D, Gray R, Quirke P (2011) Value of mismatch repair, KRAS, and BRAF mutations in predicting recurrence and benefits from chemotherapy in colorectal cancer. J Clin Oncol 29(10): 1261-1270.

Ikediobi ON, Davies H, Bignell G, Edkins S, Stevens C, O’Meara S, Santarius T, Avis T, Barthorpe S, Brackenbury L, Buck G, Butler A, Clements J, Cole J, Dicks E, Forbes S, Gray K, Halliday K, Harrison R, Hills K, Hinton J, Hunter C, Jenkinson A, Jones D, Kosmidou V, Lugg R, Menzies A, Mironenko T, Parker A, Perry J, Raine K, Richardson D, Shepherd R, Small A, Smith R, Solomon H, Stephens P, Teague J, Tofts C, Varian J, Webb T, West S, Widaa S, Yates A, Reinhold W, Weinstein JN, Stratton MR, Futreal PA, Wooster R (2006) Mutation analysis of 24 known cancer genes in the NCI-60 cell line set. Mol Cancer Ther 5(11): 2606-2612.

Imamura Y, Morikawa T, Liao X, Lochhead P, Kuchiba A, Yamauchi M, Qian ZR, Nishihara R, Meyerhardt J, Haigis K, Fuchs CS, Ogino S (2012) Specific Mutations in KRAS codons 12 and 13, and patient prognosis in 1075 BRAF-wild-type colorectal cancers. Clin Cancer Res 18(17): 4753-4763.

Inoue Y, Saigusa S, Iwata T, Okugawa Y, Toiyama Y, Tanaka K, Uchida K, Mohri Y, Kusunoki M (2012) The prognostic value of KRAS mutations in patients with colorectal cancer. Oncol Reports 28(5): 1579-1584.

Lee S, Cho NY, Choi M, Yoo EJ, Kim JH, Kang GH (2008) Clinicopathological features of $\mathrm{CpG}$ island methylator phenotype-positive colorectal cancer and its adverse prognosis in relation to KRAS/BRAF mutation. Pathol Int 58(2): 104-113.

Lin AY, Buckley NS, Lu AT, Kouzminova NB, Salpeter SR (2011) Effect of KRAS mutational status in advanced colorectal cancer on the outcomes of anti-epidermal growth factor receptor monoclonal antibody therapy: a systematic review and meta-analysis. Clin Colorectal Cancer 10(1): 63-69.

Lindor NM, Burgart LJ, Leontovich O, Goldberg RM, Cunningham JM, Sargent DJ, Walsh-Vockley C, Petersen GM, Walsh MD, Leggett BA, Young JP, Barker MA, Jass JR, Hopper J, Gallinger S, Bapat B, Redston M, Thibodeau SN (2002) Immunohistochemistry versus microsatellite instability testing in phenotyping colorectal tumors. J Clin Oncol 20(4): 1043-1048.

Moons KG, Donders RA, Stijnen T, Harrell Jr. FE (2006) Using the outcome for imputation of missing predictor values was preferred. J Clin Epidemiol 59(10): 1092-1101.

Nash GM, Gimbel M, Cohen AM, Zeng ZS, Ndubuisi MI, Nathanson DR, Ott J, Barany F, Paty PB (2010) KRAS mutation and microsatellite instability: two genetic markers of early tumour development that influence the prognosis of colorectal cancer. Ann Surg Oncol 17(2): $416-424$.
Newcomb PA, Baron J, Cotterchio M, Gallinger S, Grove J, Haile R, Hall D, Hopper JL, Jass J, Le Marchand L, Limburg P, Lindor N, Potter JD, Templeton AS, Thibodeau S, Seminara D (2007a) Colon cancer family registry: an international resource for studies of the genetic epidemiology of colon cancer. Cancer Epidemiol Biomarkers Prev 16(11): 2331-2343.

Newcomb PA, Zheng Y, Chia VM, Morimoto LM, Doria-Rose VP, Templeton A, Thibodeau SN, Potter JD (2007b) Estrogen plus progestin use, microsatellite instability, and the risk of colorectal cancer in women. Cancer Res 67(15): 7534-7539.

Ogino S, Meyerhardt JA, Irahara N, Niedzwiecki D, Hollis D, Saltz LB, Mayer RJ, Schaefer P, Whittom R, Hantel A, Benson 3rd AB, Goldberg RM, Bertagnolli MM, Fuchs CS (2009a) KRAS mutation in stage III colon cancer and clinical outcome following intergroup trial CALGB 89803. Clin Cancer Res 15(23): 7322-7329.

Ogino S, Nosho K, Kirkner GJ, Kawasaki T, Meyerhardt JA, Loda M, Giovannucci EL, Fuchs CS (2009b) CpG island methylator phenotype, microsatellite instability, BRAF mutation and clinical outcome in colon cancer. Gut 58(1): 90-96.

Oliner K, Juan T, Suggs S, Wolf M, Sarosi I, Freeman DJ, Gyuris T, Baron W, Bakker A, Parker A, Patterson SD (2010) A comparability study of 5 commercial KRAS tests. Diagnostic pathol 5: 23.

Richman SD, Seymour MT, Chambers P, Elliott F, Daly CL, Meade AM, Taylor G, Barrett JH, Quirke P (2009) KRAS and BRAF mutations in advanced colorectal cancer are associated with poor prognosis but do not preclude benefit from oxaliplatin or irinotecan: results from the MRC FOCUS trial. J Clin Oncol 27(35): 5931-5937.

Roth AD, Tejpar S, Delorenzi M, Yan P, Fiocca R, Klingbiel D, Dietrich D, Biesmans B, Bodoky G, Barone C, Aranda E, Nordlinger B, Cisar L, Labianca R, Cunningham D, Van Cutsem E, Bosman F (2010) Prognostic role of KRAS and BRAF in stage II and III resected colon cancer: results of the translational study on the PETACC-3, EORTC 40993, SAKK 60-00 trial. J Clin Oncol 28(3): 466-474.

Samowitz WS, Curtin K, Schaffer D, Robertson M, Leppert M, Slattery ML (2000) Relationship of Ki-ras mutations in colon cancers to tumour location, stage, and survival: a population-based study. Cancer Epidem Biomar 9(11): 1193-1197.

Shia J (2008) Immunohistochemistry versus microsatellite instability testing for screening colorectal cancer patients at risk for hereditary nonpolyposis colorectal cancer syndrome. Part I. The utility of immunohistochemistry. J Mol Diagn 10(4): 293-300.

Sterne JA, White IR, Carlin JB, Spratt M, Royston P, Kenward MG, Wood AM, Carpenter JR (2009) Multiple imputation for missing data in epidemiological and clinical research: potential and pitfalls. BMJ 338 : b2393.

Therneau TM, Grambsch PM (2000) Modeling Survival Data: Extending the Cox Model. Springer: New York, NY, USA.

Wang C, van Rijnsoever M, Grieu F, Bydder S, Elsaleh H, Joseph D, Harvey J, Iacopetta B (2003) Prognostic significance of microsatellite instability and Ki-ras mutation type in stage II colorectal cancer. Oncology 64(3): 259-265.

World Health Organization (2000) International Classification of Diseases for Oncology. WHO: Geneva, Switzerland.

World Health Organization (2007) International Classification of Diseases. WHO: Geneva, Switzerland.

Yamauchi M, Morikawa T, Kuchiba A, Imamura Y, Qian ZR, Nishihara R, Liao X, Waldron L, Hoshida Y, Huttenhower C, Chan AT, Giovannucci E, Fuchs C, Ogino S (2012) Assessment of colorectal cancer molecular features along bowel subsites challenges the conception of distinct dichotomy of proximal versus distal colorectum. Gut 61(6): $847-854$.

This work is published under the standard license to publish agreement. After 12 months the work will become freely available and the license terms will switch to a Creative Commons AttributionNonCommercial-Share Alike 3.0 Unported License.

Supplementary Information accompanies this paper on British Journal of Cancer website (http://www.nature.com/bjc) 